This article was downloaded by: [Linda M. Chatters]

On: 02 November 2011, At: 13: 34

Publisher: Routledge

Informa Ltd Registered in England and Wales Registered Number: 1072954 Registered office: Mortimer House, 37-41 Mortimer Street, London W1T 3J H, UK

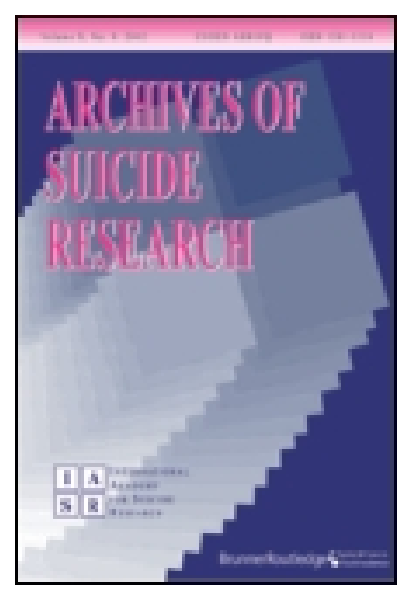

\title{
Archives of Suicide Research
}

Publication details, including instructions for authors and subscription information:

http:// www. tandfonline.com/loi/ usui20

\section{Church-Based Social Support and Suicidality Among African Americans and Black Caribbeans}

Linda M. Chatters $^{\mathrm{a}}{ }^{\mathrm{b}}$, Robert J oseph Taylor ${ }^{\mathrm{b}}$, Karen D. Lincoln ${ }^{c}$, Ann Nguyen ${ }^{b} \&$ Sean J oe ${ }^{b}$

a School of Public Health, University of Michigan, Ann Arbor, Ann Arbor, Michigan, USA

${ }^{\mathrm{b}}$ School of Social Work, University of Michigan, Ann Arbor, Ann Arbor, Michigan, USA

' School of Social Work, University of Southern California LoS Angeles, California, USA

Available online: 24 Oct 2011

To cite this article: Linda M. Chatters, Robert J oseph Taylor, Karen D. Lincoln, Ann Nguyen \& Sean J oe (2011): Church-Based Social Support and Suicidality Among African Americans and Black Caribbeans, Archives of Suicide Research, 15:4, 337-353

To link to this article: http:// dx.doi.org/10.1080/13811118.2011.615703

\section{PLEASE SCROLL DOWN FOR ARTICLE}

Full terms and conditions of use: http://www.tandfonline.com/page/terms-and-conditions

This article may be used for research, teaching, and private study purposes. Any substantial or systematic reproduction, redistribution, reselling, loan, sub-licensing, systematic supply, or distribution in any form to anyone is expressly forbidden.

The publisher does not give any warranty express or implied or make any representation that the contents will be complete or accurate or up to date. The accuracy of any instructions, formulae, and drug doses should be independently verified with primary sources. The publisher shall not be liable for any loss, actions, claims, proceedings, demand, or costs or damages whatsoever or howsoever caused arising directly or indirectly in connection with or arising out of the use of this material. 


\title{
Church-Based Social Support and Suicidality Among African Americans and Black Caribbeans
}

\author{
Linda M. Chatters, Robert Joseph Taylor, Karen D. Lincoln, \\ Ann Nguyen, and Sean Joe
}

\begin{abstract}
This study explores the relationship between church-based informal social support and lifetime prevalence of suicide ideation and attempts within a representative national sample of African American and Black Caribbean adults. Characteristics of church-based social support networks, as well as emotional support and negative interaction with church members were examined in relation to lifetime suicide ideation and attempts. This study used data from the National Survey of American Life (2001-2003). Frequency of interaction with church members was positively associated with suicide attempts, while subjective closeness to church members was negatively associated with suicide ideation. Emotional support, service attendance, and negative interaction with church members were unrelated to both suicide ideation and attempts. Findings are discussed in relation to research on church-based support networks, different models linking church support and suicidality, and the mechanisms by which church-based networks deter suicide ideation and attempts.
\end{abstract}

Keywords Afro-Caribbean, informal support network, non-kin social support, religion

Religious institutions have been a central feature in African American life, both historically and currently (Billingsley, 1999). African Americans demonstrate high levels of religious involvement as reflected in the centrality of religion and churches in individual and community life, as well as overall high rates of public religious participation (e.g., church attendance) and private devotional behaviors (e.g., prayer), expressions of religious sentiments and identities, and reliance on church-based support networks (Taylor, Chatters, \& Levin, 2004). Recent research on religious participation among Black Caribbeans also indicates that religion and churches play an important role in their lives (Bashi, 2007; Maynard-Reid, 2000; McAlister, 1998; Waters, 1999). Black Caribbean churches have a long-standing tradition of helping immigrants adapt to daily life in the United States. Black Caribbean churches provide social and psychological support to both immigrants and to those in need. They also help Black Caribbeans maintain a sense of ethnic identity and mediate the broader racial, social, and cultural environments for immigrants (Bashi, 2007; Waters, 1999). Research by Chatters and colleagues (Chatters, Taylor, Bullard et al., 2009; 
Chatters, Taylor, Jackson et al., 2008; Taylor, Chatters, \& Jackson, 2007) found that Black Caribbeans and African Americans have equally high levels of service attendance, nonorganizational religious participation (private prayer, reading religious materials, watching or listening to religious television and radio programs), subjective religiosity (perceptions and attitudes regarding religion, such as perceived importance of religion), and religious coping. Additionally, both groups have significantly higher levels of religious participation than non-Hispanic Whites (Chatters, Taylor, Bullard et al., 2009; Chatters, Taylor, Jackson et al., 2008).

Religion's protective role in relation to suicidality (e.g., religious proscriptions against suicide, behavioral and attitudinal commitments to religious concerns, religious coping strategies and resources) is an especially prominent theme in research on African Americans and one that is often cited to explain their generally lower rates of suicidality (Early, 1992; Neeleman, Wessley, \& Lewis, 1998). Similar to research findings in other population groups, high rates of religiosity are associated with lower rates of suicidality (Early, 1992; Kaslow, Price, Wyckoff et al., 2004; Kaslow, Thompson, Okun et al., 2002; Neelman, Wessley, \& Lewis, 1998) among African Americans. One would also expect that religious participation would be protective of suicidal behavior among Black Caribbeans.

Although prior research indicates that organizational religious involvement (e.g., service attendance) is negatively associated with suicidal behaviors (Kaslow, Price, Wyckoff et al., 2004), we have little understanding regarding how attendance operates in relation to suicidality and whether it is essentially a proxy for other factors and processes. Research and theory on religion-health associations suggest that high levels of social integration and social support within religious settings are important constructs linking religion and positive health outcomes (Chatters, 2000; Ellison \& Levin, 1998; Krause, 2008). Social support is an important protective factor that operates in several ways (e.g., direct health effects, moderating negative effects of stressors) to enhance overall health status and improve health outcomes (Berkman \& Glass, 2000; Cassel 1976; House, Landis, \& Umberson, 1988). Recent research identifies social support networks within religious communities as important protective factors for physical and mental health, particularly when individuals are faced with the negative effects of illness and other life stressors (Krause, 2008).

Church-based social support networks figure prominently in the lives of African Americans and play an important role in physical and mental health and well-being (Krause, 2008; Taylor \& Chatters, 1986a, 1986b, 1988; Taylor, Chatters, \& Levin, 2004; Taylor, Lincoln, \& Chatters, 2005). African Americans are strongly invested in church-based networks that provide high levels of social support, social integration, and cohesion (see Taylor, Chatters, \& Levin et al., 2004 for a discussion). The prominence of church-based social support networks for African Americans and their positive associations with mental health and well-being suggests that they could be linked to lower levels of suicidality.

The present analysis is the first examination of the relationship between involvement in church-based social support networks and life-time suicidality (e.g., ideation, attempts) among a national sample of African Americans and Caribbean Blacks. Our specific focus is to examine the associations between life-time reports of suicide ideation and attempts and: (1) church-based support network characteristics (e.g., frequency of interaction, subjective closeness); (2) perceptions of emotional support from church members; and (3) reports of negative interactions (e.g., being criticized) from church members. These analyses are 
conducted within a representative sample of African Americans and Black Caribbeans (National Survey of American Life 2001-2003) and control for demographic characteristics known to be associated with both religious involvement and suicide risk (e.g., gender, age, marital status, socioeconomic position). The present analysis also controls for the effects of any psychiatric disorder.

The literature review begins with a survey of current research on church-based social support, with specific attention to studies involving African American populations. Topics reviewed include the nature and functions of church-based support networks. Next, we examine research demonstrating both positive influences of receiving emotional support from church members, as well as the harmful impacts of negative social interactions with church members on health and well-being.

\section{CHURCH-BASED SUPPORT NETWORKS}

African American churches have historically provided extensive community outreach efforts in the areas of health and social welfare, education, and community organizing and development (Billingsley, 1999; Caldwell, Chatters, Billingsley et al., 1995; Lincoln \& Mamiya, 1990). In addition to these outreach efforts, informal social support networks operating within African American churches (i.e., churchbased support networks) also provide significant amounts of assistance to church members (Chatters, Taylor, Lincoln et al., 2002; Taylor, Chatters, \& Levin, 2004; Taylor, Lincoln, \& Chatters, 2005). This includes tangible assistance such as monetary aid, in-kind services, and help with transportation, housing, job referrals, and caregiving, as well as non-tangibles such as emotional support, information, and counseling and advice (Taylor, Lincoln, \& Chatters, 2005).
Despite the prominence of churchbased networks as sources of social support for African Americans, until recently, very little research systematically examined these relationships (Krause, 2008; Taylor \& Chatters, 1986a, 1988; Taylor, Chatters, \& Levin, 2004). Work by Taylor and associates found that the majority of African American adults receive some form of assistance from church-based networks (Taylor \& Chatters, 1986a, 1986b, 1988; Taylor, Lincoln, \& Chatters, 2005). Individuals who are invested and integrated in church networks (i.e., those who are official members, attend frequently, interact often and feel emotionally close to church members) are more likely to receive support (Krause, 2002a, 2002b, 2004; Taylor \& Chatters, 1988; Taylor, Lincoln, \& Chatters, 2005). Further, studies among older adults indicate that African Americans, as compared to their White counterparts, report higher levels of church-based emotional support, spiritual support, and congregational cohesiveness and are more likely to experience the health benefits of church support (Krause, 2002a, 2002b, 2008, 2010).

Church-based support networks provide assistance and resources (e.g., emotional, material, instrumental, psychosocial) that are essential elements in coping with life problems and stressful events (Chatters, 2000; Ellison \& Levin, 1998; Koenig, McCullough, \& Larson, 2001; Krause, 2008). Tangible and instrumental resources from church-based networks directly address material needs such as food, shelter, and clothing that are relevant for health and well-being. The negative consequences associated with stressful events (e.g., poor health, psychological distress, depression) are thought to result, in part, from the erosion of self-regarding beliefs such as self-worth, self-esteem, and personal control (Chatters, 2000; Ellison \& Levin, 1998; Krause, 2008). However, psychosocial, emotional, and 
spiritual support from church members potentially buffers the negative impact of stressful events on health by bolstering these self-perceptions.

Research examining the health-related benefits of church-based support on mental and physical health and psychological wellbeing (Koenig, McCullough, \& Larson, 2001; Krause, 2004, 2006a, 2006b, 2008) indicates that support from church members is associated with positive self-rated health (Krause, 2006a), life satisfaction (Krause, 2004, 2008), health care use (Krause, 2010), and lower mortality rates (Krause, 2006b). For example, older African Americans who received higher levels of emotional support from church members were more likely to state that religion was particularly important in dealing with problems associated with race (Krause, 2004) and, in addition, reported higher levels of life satisfaction (p. S114). Support from church members lessened the impact of financial strain on self-rated health among older Black adults but not older Whites (Krause, 2006a). Finally, current evidence indicates that individuals with extensive involvement and commitment to these social ties are more likely to benefit from church-based networks and relationships (Krause, 2008; Taylor, Chatters, \& Levin, 2004; Taylor, Lincoln, \& Chatters, 2005).

Notwithstanding the positive aspects of church-based support, involvement in church networks is associated with negative social interactions as well. These include problematic social interactions, interpersonal conflicts with clergy and church members, disagreements over church policy, doctrine and practices, and public censure for inappropriate behaviors (Chatters, 2000; Ellison \& Levin, 1998; Krause, 2008; Krause, Chatters, Meltzer et al., 2000; Taylor, Chatters, \& Levin, 2004). Theory and research on negative social interactions indicate that they are distinct from social support, their impact on overall well-being and mental health is particularly distressing and, in comparison to the positive impact of socially supportive interactions, their detrimental effects on well-being are more potent (Lincoln, 2000; Lincoln, Chatters \& Taylor, 2003; Lincoln, Taylor, \& Chatters, 2003; Rook, 1984).

The church support variables that are examined in this analysis have been adapted from research in family sociology. They are consistent with research on family solidarity by Landecker (1951) and Nye and Rushing (1969), as well as more recent work by Bengtson and colleagues (Bengtson, Giarrusso, Mabry et al., 2002). Specifically, the family solidarity model and constructs (e.g., affectional solidarity, functional solidarity) focus on specific characteristics that are associated with interaction and tasks performed by family networks. These characteristics include network affection (i.e., positive sentiments about network members), association (i.e., frequency of interaction), and function (i.e., exchanges of various types of support). Church networks, particularly among African Americans, are noted for their close parallels to family and kin-based networks (Taylor, Chatters, \& Levin, 2004). Church networks are frequently described in terms of kinship relationships and structures whereby people in the church are often regarded as one's "church family" and fellow congregation members are called "Brother" or "Sister" (Lincoln \& Mamiya, 1990). The analysis also includes a measure of negative interaction with church members which allows for an assessment of the impact of negative, as well as positive aspects of church-based networks on suicidal behavior.

\section{METHODS}

\section{Sample}

The National Survey of American Life: Coping with Stress in the 21st Century 
(NSAL) was collected by the Program for Research on Black Americans at the University of Michigan's Institute for Social Research (Jackson, Torres, Caldwell et al., 2004). The field work for the study was completed by the Institute of Social Research's Survey Research Center, in cooperation with the Program for Research on Black Americans. After a complete description of the study was provided to participants, informed consent was obtained. The Institutional Review Board of the University of Michigan approved the recruitment, consent, and data collection procedures.

A total of 6,082 interviews were conducted with persons aged 18 or older, including 3,570 African Americans, 891 non-Hispanic Whites, and 1,621 Blacks of Caribbean descent. The NSAL includes the first major probability sample of Caribbean Blacks ever conducted. For the purposes of this study, Caribbean Blacks are defined as persons who trace their ethnic heritage to a Caribbean country, but who now reside in the United States, are racially classified as Black, and who are English-speaking (but may also speak another language).

The NSAL sample has a national multi-stage probability design. The overall response rate was $72.3 \%$. The interviews were face-to-face and conducted within respondents' homes. Respondents were compensated for their time. The data collection was conducted from 2001 to 2003. Response rates for individual subgroups were $70.7 \%$ for African Americans, 77.7\% for Caribbean Blacks, and $69.7 \%$ for non-Hispanic Whites. This response rate is excellent considering that African Americans (especially lower income African Americans) and Caribbean Blacks are more likely to reside in major urban areas where it is more difficult and much more expensive to collect interviews. Final response rates for the NSAL two-phase sample designs were computed using the
American Association of Public Opinion Research (AAPOR) guidelines for Response Rate 3 (AAPOR, 2006).

The non-Hispanic Whites in the NSAL sample were not administered the full interview and were not asked the suicidality questions. Additionally, this study investigates the role of church support networks on suicidal behavior. The church support network questions were not asked to respondents who indicated that they attend religious services less than once per year or that they never attend religious services. Consequently, the present study focuses on African Americans and Caribbean Blacks who attend religious services at least a few times a year $(82.5 \%$ of the sample). The analytic sample for this study is 2,870 African Americans and 1,256 Black Caribbeans who attend religious services at least a few times a year $(N=4,126)$.

The African American sample is the core sample of the NSAL. The core sample consists of 64 primary sampling units (PSUs). Fifty-six of these primary areas overlap substantially with existing Survey Research Center's National Sample primary areas. The remaining eight primary areas were chosen from the South in order for the sample to represent African Americans in the proportion in which they are distributed nationally. Both the African American and White samples were selected exclusively from these targeted geographic segments in proportion to the African American population. The Caribbean Black sample was selected from two area probability sample frames: the core NSAL sample and an area probability sample of housing units from geographic areas with a relatively high density of persons of Caribbean descent.

In both the African American and Black Caribbean samples, it was necessary for respondents to self-identify their race as Black. Those self-identifying as Black were included in the Caribbean Black sample if they answered affirmatively when 
asked if they were of West Indian or Caribbean descent, said they were from a country included on a list of Caribbean area countries presented by the interviewers, or indicated that their parents or grandparents were born in a Caribbean area country (see Heeringa, Wagner, Torres et al., 2004 and Jackson, Torres, Caldwell et al., 2004 for a more detailed discussion of the NSAL sample).

\section{Measures}

Suicidal Behavior. Suicidality is assessed in its own section of the World Mental Health Composite International Diagnostic Interview (WMH-CIDI) by a series of questions about lifetime suicidal behaviors (Joe, Baser, Breeden et al., 2006; Kessler, Berglund, Borges et al., 2005). Respondents were screened into the suicidality section of the WMH-CIDI if they answered affirmatively to the question "Have you ever seriously thought about committing suicide?" These respondents are classified as having engaged in suicidal ideation. Only those who have engaged in suicidal ideation were asked the question "Have you ever attempted suicide?" These respondents are classified as having attempted suicide.

Independent Variables. Several aspects of church-based informal social support are assessed in this study including: degree of subjective closeness; frequency of interaction with church members; receipt of emotional support; and frequency of negative interactions with church members. Degree of subjective closeness is measured by the question, "How close are you to the people in your church? Would you say very close, fairly close, not too close, or not close at all?" Frequency of interaction with church members is measured by the question "How often do you see, write, or talk on the telephone with members of your church (place of worship)? Would you say nearly every day, at least once a week, a few times a month, at least once a month, a few times a year or never?"

Emotional support from church members is measured by an index of three items. Respondents were asked "How often do your church members: (1) make you feel loved and cared for, (2) listen to you talk about your private problems and concerns, and 3) express interest and concern in your well-being?" Response categories range from very often to never with higher values on this index indicating higher levels of social support. Cronbach's alpha for this 3 -item index is .70. Negative interaction with church members is also measured by an index of 3 items. Respondents were asked "how often do your church members: (1) make too many demands on you? (2) criticize you and the things you do? and (3) try to take advantage of you?" The response categories for these questions were "very often," "fairly often," "not too often" and "never." Higher values on this index indicate higher levels of negative interaction with family members (Cronbach's alpha $=.72$ ). For purposes of bivariate analysis only, low, medium, and high levels of emotional support and negative interaction were derived from tertiles of the indices.

Frequency of religious service attendance is measured by combining two questions: "Other than for weddings or funerals, have you attended services at a church or other place of worship since you were 18 years old?" (YES/NO) and "How often do you usually attend religious services?" The categories for this combined variable are: attend nearly every day; attend at least once a week; a few times a month; a few times a year; less than once a year; and never. Please note that because the church network variables are only asked of individuals who attend church at least a few times a year, the analysis does not include respondents who attend church less than once a year or who never attend. 
The demographic variables used in this analysis include ethnicity, age, gender, marital status, education, and family income. Missing data for family income and education were imputed using an iterative regression-based multiple imputation approach incorporating information about age, sex, region, race, employment status, marital status, home ownership, and nativity of household residents. Finally, using the mental disorders sections from the NSAL, this analysis controls for presence of any major psychiatric disorder within the past 12 months. The NSAL mental disorders sections are slightly modified versions of those developed for the World Mental Health project initiated in 2000 (World Health Organization, 2004) and the instrument used in the National Comorbidity Study-Revised (Kessler \& Ustun, 2004). The analysis controls for whether respondents had any anxiety disorder (panic disorder, agoraphobia, social phobia, generalized anxiety disorder, obsessive compulsive disorder, posttraumatic stress disorder), mood disorder (major depressive disorder, dysthymia, bipolar I \& II disorders), substance disorder (alcohol abuse, alcohol dependence, drug abuse, drug dependence), eating disorder (anorexia, bulimia, binge-eating), or disorder usually diagnosed in childhood (separation anxiety, oppositional defiant disorder, conduct disorder, attention deficit/hyperactivity disorder). Obsessive compulsive disorder was assessed using the CIDI-Short Forms (Kessler, Andrews, Mroczek et al., 1998).

\section{Analysis Strategy}

First, bivariate associations are tested with a design-based $F$ statistic from cross-tabulation. The percentages represent weighted proportions based on the distribution of African Americans in the population. The standard errors reflect the recalculation of variance using the study's complex design. The Rao-Scott $\chi^{2}$ represents a complex design-corrected measure of association. For the multivariate analyses logistic regression was used. Odds ratio estimates and 95\% confidence intervals are presented along with the design-corrected F statistic. The regression coefficients and standard errors take into account the complex multistage clustered design of the NSAL sample, unequal probabilities of selection, nonresponse, and poststratification. All analyses were conducted using SAS 9.13 which uses the Taylor expansion approximation technique for calculating the complex design-based estimates of variance.

\section{RESULTS}

The distribution of the sample and study variables is presented in Table 1 . The lifetime prevalence rate is $3.88 \%$ for suicidal attempts and $10.87 \%$ for suicidal ideation. Respondents reported receiving emotional support from church members $(\mathrm{M}=8.81)$ more frequently than negative interactions $(\mathrm{M}=4.48)$. Additionally, $19.4 \%$ of respondents indicate that they interact with their church members nearly every day and 34.5\% of respondents report being very close to their church members.

The bivariate analysis of the church support variables and frequency of service attendance on suicidal attempts and suicidal ideation are presented in Table 2. Service attendance was the only religion variable to have a significant bivariate relationship with suicidal attempts. Respondents who attended religious services at least once per week had the lowest likelihood of ever having a suicidal attempt while those who attended nearly every day had the highest likelihood.

Frequency of service attendance, degree of subjective closeness to church members and receipt of emotional support from church members were all significantly 
TABLE 1. Demographic Characteristics of the Sample and Distribution of Study Variables

\begin{tabular}{|c|c|c|}
\hline & $\%$ (Mean) & N (S.D.) \\
\hline Church Attendance & 4.27 & 0.69 \\
\hline Church Member Interaction & 3.65 & 1.39 \\
\hline Closeness to Church Members & 2.97 & 0.73 \\
\hline Emotional Support from Church Members & 8.81 & 1.84 \\
\hline Negative Interaction with Church Members & 4.48 & 1.42 \\
\hline \multicolumn{3}{|l|}{ Ethnicity } \\
\hline African American & 93.17 & 2870 \\
\hline Black Caribbean & 6.83 & 1256 \\
\hline \multicolumn{3}{|l|}{ Gender } \\
\hline Male & 42.13 & 1403 \\
\hline Female & 57.86 & 2723 \\
\hline \multicolumn{3}{|l|}{ Age } \\
\hline $18-34$ & 35.21 & 1413 \\
\hline $35-54$ & 42.64 & 1775 \\
\hline $55+$ & 22.14 & 938 \\
\hline \multicolumn{3}{|l|}{ Education } \\
\hline Less than High School & 22.60 & 921 \\
\hline High School Graduate & 35.75 & 1425 \\
\hline Some College & 25.58 & 1036 \\
\hline College Graduate & 16.06 & 744 \\
\hline \multicolumn{3}{|l|}{ Family Income } \\
\hline Less than $\$ 18,000$ & 29.23 & 1318 \\
\hline$\$ 18,000-\$ 31,999$ & 24.02 & 1056 \\
\hline$\$ 32,000-\$ 54,999$ & 24.07 & 941 \\
\hline$\$ 55,000+$ & 22.67 & 811 \\
\hline \multicolumn{3}{|l|}{ Marital Status } \\
\hline Married/Partner & 43.99 & 1576 \\
\hline Widowed, Separated, Divorced & 26.78 & 1280 \\
\hline Never married & 29.22 & 1270 \\
\hline \multicolumn{3}{|l|}{ Any Disorder } \\
\hline Yes & 38.05 & 1449 \\
\hline No & 61.95 & 2671 \\
\hline \multicolumn{3}{|l|}{ Suicidal Attempt } \\
\hline Yes & 3.88 & 146 \\
\hline No & 96.12 & 3980 \\
\hline \multicolumn{3}{|l|}{ Suicidal Ideation } \\
\hline Yes & 10.87 & 418 \\
\hline No & 89.13 & 3708 \\
\hline
\end{tabular}

Note. Percents and N are presented for categorical variables and Means and Standard Deviations are presented for continuous variables. Percentages are weighted and frequencies are unweighted. 
L. M. Chatters et al.

TABLE 2. Bivariate Analysis of Informal Church Support on Suicidal Attempts and Ideation among African Americans and Black Caribbeans ${ }^{a}$

\begin{tabular}{|c|c|c|c|c|}
\hline & \multicolumn{2}{|c|}{ Attempt } & \multicolumn{2}{|c|}{ Ideation } \\
\hline & $n$ & $\%$ & $n$ & $\%$ \\
\hline \multicolumn{5}{|c|}{ Church Member Interaction } \\
\hline Nearly Every Day & 34 & 4.25 & 82 & 10.11 \\
\hline Once a Week & 24 & 3.23 & 75 & 8.86 \\
\hline Few Times a Month & 24 & 5.93 & 61 & 13.35 \\
\hline Once a Month & 14 & 3.84 & 35 & 9.17 \\
\hline A Few Times a Year & 18 & 2.65 & 62 & 10.04 \\
\hline Never & 32 & 3.58 & 103 & 13.40 \\
\hline Rao-Scott $\chi 2$ & \multicolumn{2}{|c|}{5.84} & \multicolumn{2}{|c|}{7.83} \\
\hline $\mathrm{P}$ & \multicolumn{2}{|c|}{0.3214} & \multicolumn{2}{|c|}{0.1653} \\
\hline $\mathrm{N}$ & \multicolumn{2}{|c|}{4123} & \multicolumn{2}{|c|}{4123} \\
\hline \multicolumn{5}{|c|}{ Closeness to Church Members } \\
\hline Very Close & 42 & 3.86 & 111 & 8.53 \\
\hline Fairly Close & 47 & 2.92 & 147 & 9.94 \\
\hline Not Too Close & 36 & 5.46 & 87 & 13.67 \\
\hline Not Close At All & 20 & 4.80 & 71 & 16.76 \\
\hline Rao-Scott $\chi^{2}$ & \multicolumn{2}{|c|}{5.22} & \multicolumn{2}{|c|}{19.60} \\
\hline $\mathrm{P}$ & \multicolumn{2}{|c|}{0.1558} & \multicolumn{2}{|c|}{0.0002} \\
\hline $\mathrm{N}$ & \multicolumn{2}{|c|}{4116} & \multicolumn{2}{|c|}{4116} \\
\hline \multicolumn{5}{|l|}{ Emotional Support } \\
\hline High & 55 & 4.11 & 150 & 9.89 \\
\hline Medium & 36 & 3.01 & 106 & 9.16 \\
\hline Low & 55 & 4.55 & 161 & 13.91 \\
\hline Rao-Scott $\chi 2$ & \multicolumn{2}{|c|}{2.59} & \multicolumn{2}{|c|}{12.26} \\
\hline $\mathrm{P}$ & \multicolumn{2}{|c|}{0.27} & \multicolumn{2}{|c|}{0.0022} \\
\hline $\mathrm{N}$ & \multicolumn{2}{|c|}{4112} & \multicolumn{2}{|c|}{4112} \\
\hline \multicolumn{5}{|l|}{ Negative Interaction } \\
\hline High & 38 & 4.13 & 106 & 11.63 \\
\hline Medium & 38 & 3.98 & 129 & 11.12 \\
\hline Low & 70 & 3.70 & 182 & 10.13 \\
\hline Rao-Scott $\chi 2$ & \multicolumn{2}{|c|}{0.21} & \multicolumn{2}{|c|}{1.0022} \\
\hline $\mathrm{P}$ & \multicolumn{2}{|c|}{0.8991} & & \\
\hline $\mathrm{N}$ & & & & \\
\hline Service Attendance & & & & \\
\hline Nearly Every Day & 16 & 6.57 & 34 & 13.19 \\
\hline At Least Once per Week & 41 & 2.48 & 130 & 8.14 \\
\hline A Few Times a Month & 45 & 4.36 & 129 & 10.95 \\
\hline A Few Times per Year & 44 & 4.84 & 125 & 14.49 \\
\hline
\end{tabular}

(Continued) 


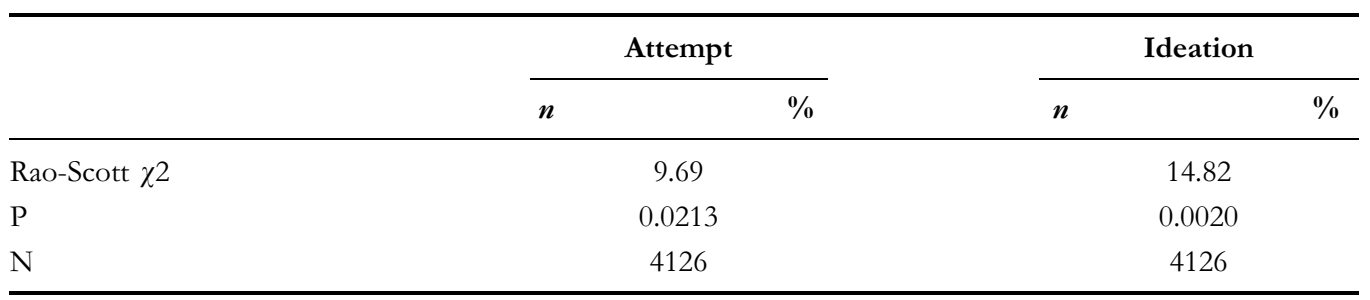

Note. Data are presented as unweighted frequencies and weighted percentages.

${ }^{a}$ Reported Ns represent respondents who indicate 'Yes' to suicide attempts or 'Yes' to ideation.

associated with suicidal ideation. Respondents who attended religious services at least once per week were the least likely to report suicidal ideations, whereas those who attended services a few times a year were the most likely to report suicidal ideations. Both closeness to church members and receipt of emotional support were negatively associated with suicidal ideation: respondents who reported being very close to their fellow church members and respondents who reported receiving high levels of emotional support from church members were less likely than their counterparts to have ever had suicidal ideations.

Table 3 presents the logistic regressions of the church support variables, service attendance, and demographic controls on suicidal attempts and ideation. Previous research using this sample indicated a significant interaction between gender and ethnicity on suicidal attempts (Joe, Baser, Breeden et al., 2006). Consequently, we control for this relationship in our logistic regression analysis of attempts. Among the religion and church support variables, only frequency of interaction with church members was significantly associated with suicidal attempts. Frequency of interaction with church members was positively associated with the likelihood of having a lifetime suicidal attempt $(\mathrm{OR}=1.14,95 \%$ $\mathrm{CI}=1.02-1.27)$ indicating that respondents who reported a suicidal attempt in their lifetime interacted with their church members on a more frequent basis.
Subjective closeness to church members was the only church support variable that was significantly associated with suicidal ideation $(\mathrm{OR}=0.79,95 \% \mathrm{CI}=.67-$ .93). Respondents who felt subjectively closer to their church members were less likely to indicate that they had suicidal ideations. Ancillary analysis indicated that frequency of receiving emotional support from church members was also significantly associated with suicidal ideation, but only when subjective closeness to church members was not included in the analysis. When both variables were included in the model, only subjective closeness to church members maintained significance.

We tested several interactions in the analysis of both suicidal attempts and suicidal ideation. In particular, we tested interactions between: (1) ethnicity (African American, Black Caribbean) and frequency of interaction with church members; (2) ethnicity and subjective closeness to church members; (3) ethnicity and emotional support from church members; and (4) ethnicity and negative interaction with church members. None of these interactions were significant, so they were not included in the final models.

\section{DISCUSSION}

Research on suicidal behavior has clearly established that religion and, in particular, 
TABLE 3. Logistic Regression Analysis of Church Support on Lifetime Suicidal Attempts and Ideation among African Americans and Black Caribbeans $(N=4099)$

\begin{tabular}{|c|c|c|c|c|}
\hline & \multicolumn{2}{|c|}{ Attempts } & \multicolumn{2}{|c|}{ Ideation } \\
\hline & OR & $95 \% \mathrm{CI}$ & OR & $95 \% \mathrm{CI}$ \\
\hline Service Attendance & 0.95 & $0.70-1.28$ & 0.98 & $0.83-1.15$ \\
\hline Interaction with Church Members & 1.14 & $1.02-1.27^{*}$ & 1.05 & $0.97-1.14$ \\
\hline Closeness to Church Members & 0.81 & $0.62-1.07$ & 0.79 & $0.67-0.93^{* *}$ \\
\hline Emotional Support from Church Members & 1.00 & $0.91-1.09$ & 0.98 & $0.91-1.05$ \\
\hline Negative Interaction with Church Members & 1.04 & $0.94-1.15$ & 1.05 & $0.98-1.13$ \\
\hline \multicolumn{5}{|l|}{ Ethnicity } \\
\hline African American $^{a}$ & 1.00 & & 1.00 & \\
\hline Black Caribbean & 3.82 & $1.20-12.11^{*}$ & 1.25 & $0.79-1.98$ \\
\hline \multicolumn{5}{|l|}{ Gender } \\
\hline Male $^{a}$ & 1.00 & & 1.00 & \\
\hline Female & 1.78 & $0.95-3.33$ & 1.28 & $0.88-1.83$ \\
\hline \multicolumn{5}{|l|}{ Age } \\
\hline $18-34^{a}$ & 1.00 & & 1.00 & \\
\hline $35-54$ & 1.02 & $0.64-1.64$ & 1.14 & $0.81-1.56$ \\
\hline $55+$ & 0.69 & $0.29-1.66$ & 0.55 & $0.35-0.85^{* * *}$ \\
\hline \multicolumn{5}{|l|}{ Education } \\
\hline Less than High School & 3.73 & $1.13-12.37^{*}$ & 1.40 & $0.83-2.34$ \\
\hline High School Graduate & 2.18 & $0.64-7.44$ & 1.17 & $0.72-1.92$ \\
\hline Some College & 2.60 & $0.81-7.44$ & 1.09 & $0.67-1.76$ \\
\hline College Graduate $^{a}$ & 1.00 & & 1.00 & \\
\hline \multicolumn{5}{|l|}{ Family Income } \\
\hline Less than $\$ 18,000^{a}$ & 1.00 & & 1.00 & \\
\hline$\$ 18,000-\$ 31,999$ & 1.32 & $0.78-2.24$ & 1.08 & $0.71-1.63$ \\
\hline$\$ 32,000-54,999$ & 0.74 & $0.41-1.35$ & 0.86 & $0.60-1.25$ \\
\hline$\$ 55,000+$ & 0.47 & $0.12-1.83$ & 0.59 & $0.35-1.03$ \\
\hline \multicolumn{5}{|l|}{ Marital Status } \\
\hline Married $^{a}$ & 1.00 & & 1.00 & \\
\hline Separated/Divorced/Widowed & 0.55 & $0.28-1.07$ & 1.03 & $0.71-1.50$ \\
\hline Never Married & 0.93 & $0.53-1.64$ & 1.04 & $0.69-1.58$ \\
\hline \multicolumn{5}{|l|}{ Any 12 Month Disorder } \\
\hline Yes & 7.04 & $3.76-11.70^{* * *}$ & 4.85 & $3.50-6.71^{* * *}$ \\
\hline $\mathrm{No}^{a}$ & 1.00 & & 1.00 & \\
\hline Gender X Ethnicity & 0.16 & $0.04-0.60^{* *}$ & - & \\
\hline
\end{tabular}

$\mathrm{OR}=$ Odds Ratio, $\mathrm{CI}=$ Confidence Interval.

${ }^{a}$ Reference Category.

${ }^{*} p<0.05 ;{ }^{* *} p<0.01 ;{ }^{* * *} p<0.001$. 
religious service attendance serves as a protective factor for suicidality. As an extension of this work, the present analysis confirmed that among respondents who attended religious services at least a few times a year, supportive relationships with church members helps protect against suicidal risk. The present analysis also found that church-based social support operates similarly for African Americans and Black Caribbeans. This analysis has several notable strengths including: (1) the use of several indicators of church support; (2) examination of both positive as well as negative aspects of church support networks; (3) controls for demographic factors and major psychiatric disorders; (4) and utilizing data from a national sample.

There were two major findings in the study. First, subjective closeness to church members was inversely related to suicidal ideation. Ancillary analysis additionally indicated that receiving emotional support from church members was also inversely associated with suicidal ideation, but only when subjective closeness with church members was not included in the model. Subjective closeness to church members is an indicator of the degree to which individuals feel a sense of embeddedness and belonging with this social group which helps prevent suicidal ideations. This finding is consistent with numerous studies which find that social support from family members is inversely related to suicidal behaviors (Compton, Thompson, \& Kaslow, 2005) and to depressive symptoms (Barrera, 1986). The present finding is also consistent with the emerging body of research which finds that church based informal social support has important protective influences on physical and mental health (Krause, 2004, 2006a, 2006b, 2008, 2010).

Second, frequency of interaction with church members was positively associated with suicidal attempts. Although surprising, it would be erroneous to interpret this finding as indicating that more frequent interaction with church members is a risk factor for suicidal attempts. This finding is consistent with theoretical models of the relationship between religion and physical/mental health (Ellison \& Levin, 1998; Levin \& Chatters, 2008), as well as models of social support and physical/ mental health (Barrera, 1986). In particular, this finding is consistent with the Resource Mobilization or Stressor Response model which hypothesizes that adversity may prompt individuals to seek out assistance from their support networks. Within the context of the current findings, persons who have previously attempted suicide may be more likely to interact with church members as a general preventive strategy and/or as a means of mobilizing their support resources as part of ongoing efforts to cope with difficult circumstances. More so than any other social group, church members are less likely to engage in substance abuse, marital infidelity, criminal behavior, or other risky behaviors (Levin \& Chatters, 2008) that may be detrimental to the mental health of someone who has previously attempted suicide. Future research using prospective study designs can be used to examine the causal relationships and temporal ordering between church-based support (i.e., interaction with church members) and suicide attempts.

It is important to comment on two null findings. First, negative interaction with church members was not significantly associated with suicidal attempts or ideation. This is despite the suggestions in the literature that negative interactions with church members may be particularly problematic because they are at odds with the purported aspirations of religion to promote love and compassion (Krause, 2008). Further, although there have been only a handful of studies, prior work indicates that negative interactions with church members are associated with increased levels of depressive symptoms (Krause, 2008; Krause, 
Ellison \& Wulff, 1998) and reduced levels of satisfaction with health (Krause \& Wulff, 2005). Our findings that negative interaction with church members was not associated with suicidal behaviors, likely reflects the significant differences in the type of outcomes examined (i.e., psychological distress/health satisfaction vs. suicidality).

A second null finding indicated that religious service attendance was not significantly associated with either measure of suicidal behavior. This is probably due to the fact that our analysis was restricted to individuals who attended services at least a few times a year (those attending less than once a year or never were excluded). We investigated attendance as both a continuous variable (Table 3) as well as a categorical variable with a few times per year being the excluded category (analysis available upon request); service attendance failed to achieve significance regardless of the coding scheme. The protective aspects of service attendance may be more apparent in contrasts involving individuals who never attend religious services and those who attend regularly. Overall, the findings indicate that, among people who regularly attend religious services, factors that characterize church-based support networks (e.g., interaction, subjective closeness) were more important correlates of suicidal risk than mere service attendance. In comparing the relative significance of service attendance versus social support, however, it is important not to over-interpret these findings as confirmation that social support alone has effects on suicidality.

Social support from church members is just one of several aspects associated with attending religious services. Because service attendance is multifaceted, other aspects of attendance may have important protective effects against suicidal ideation and behavior. Specific features of religious services themselves may be helpful to individuals in dealing with problems. For example, sermons, listening to religious music, and reading religious texts, all provide messages of optimism, hope, existential meaning, and personal worth and salvation which may help individuals cope with difficult life circumstances and protect against suicidality.

Limitations of the present study should be acknowledged. The first concerns the use of single item indictors to represent two of the church support constructs (i.e., degree of subjective closeness and frequency of interaction). Previous research has argued that single items are suitable for narrow or otherwise unambiguous constructs (Sackett \& Larson, 1990). In the current analysis, asking respondents to indicate the frequency of interaction and how close they are to church members are unambiguous constructs that we believe are sufficiently narrow and easily understood by respondents. In addition, results from previous research (Taylor, Lincoln, \& Chatters, 2005) indicate that these items have face validity and function as would be theoretically expected (i.e., the hypothesized relations between theoretical constructs were confirmed). Despite having a large nationally representative sample, the results reported here are limited by relatively small numbers of individuals reporting suicidal behaviors. This is consistent with the fact that general prevalence rates for suicidal behavior are low. The numbers of respondents that report suicidal behaviors in this study are, however, consistent with similar large scale, community-based psychiatric epidemiological studies (Kessler, Berglund, Borges et al., 2005). Lastly, the Black Caribbean sample excludes individuals who do not speak English (i.e., persons who only speak Spanish, Haitian-French, or Creole dialects) and, as a consequence, the study findings are not generalizable to these groups of Caribbean Blacks.

In conclusion, specific characteristics of church-based support were associated with suicide ideation and attempts within 


\section{Church Support and Suicidal Risk}

a representative sample of African American and Black Caribbean adults. The positive association between interaction with church members and suicide attempts suggests that social interaction may function as a suicide prevention strategy or as an effort to mobilize social resources for individuals who are at known risk for future attempts. The inverse association between subjective closeness and suicide ideation confirms prior theory (Ellison \& Levin, 1998; Koenig, McCullough, \& Larson, 2001) on the protective aspects of church-based social support on mental health. In contrast, negative interaction with church members was unrelated to both suicide ideation and attempts. Null effects for service attendance on ideation and attempts suggests that: (1) attendance is ineffective in reducing suicidality in the presence of church-based supports (i.e., subjective closeness); and (2) positive effects for service attendance noted in prior studies may, in fact, have been due in part to unmeasured qualitative aspects of these relationships. These findings suggest that further research on the nature of church-based support is needed to uncover the specific pathways and mechanisms linking diverse aspects of church support and suicidality. Future research investigating help-seeking from clergy (Chatters, Mattis, Woodward et al., 2011) is also needed, as well as the influence of other aspects of church networks such as participation in church groups (e.g., choirs, women's clubs, prayer groups) on suicidal behaviors.

\section{AUTHOR NOTE}

Linda M. Chatters, School of Public Health, and School of Social Work, University of Michigan, Ann Arbor, Ann Arbor, Michigan, USA.

Robert Joseph Taylor, School of Social Work, University of Michigan, Ann Arbor, Ann Arbor, Michigan, USA.
Karen D. Lincoln, School of Social Work, University of Southern California Los Angeles, California, USA.

Ann Nguyen and Sean Joe, School of Social Work, University of Michigan, Ann Arbor, Ann Arbor, Michigan, USA.

The preparation of this manuscript was supported by grants from the National Institute of Mental Health to Drs. Joe, Chatters, and Taylor (R01-MH082807), R01-MH084963 to Dr. Lincoln and Dr. Chatters, and from the National Aging for Dr. Taylor (P30-AG15281). The data collection on which this study is based was supported by the National Institute of Mental Health (NIMH; U01MH57716) with supplemental support from the Office of Behavioral and Social Science Research at the National Institutes of Health (NIH) and the University of Michigan.

Correspondence concerning this article should be addressed to Linda M. Chatters, School of Social Work, 1080 South University Avenue, Ann Arbor, MI 48109. E-mail: chatters@umich.edu

\section{REFERENCES}

American Association for Public Opinion Research. (2006). Standard definitions: Final dispositions of case codes and outcome rates for surveys. 4th ed. Lenexa, KS: American Association for Public Opinion Research.

Barrera, Jr., M. (1986). Distinctions between social support concepts, measures and models. Journal of Community Psychology, 14, 413-445.

Bashi, V. (2007). Survival of the knitted: Immigrant social networks in a stratified world. Stanford, CA: Stanford University Press.

Bengtson, V., Giarrusso, R., Mabry, J. B., \& Silverstein, M. (2002). Solidarity, conflict, and ambivalence: Complementary or competing perspectives on intergenerational relationships? Journal of Marriage and Family, 64, 568-576.

Berkman, L. F., \& Glass, T. (2000). Social integration, social networks, social support and health. In L. Berkman and I. Kawachi (Eds.). Social 
epidemiology (pp. 137-173). New York, NY: Oxford University Press.

Billingsley, A. (1999). Mighty like a river: The Black church and social reform. New York, NY: Oxford University Press.

Caldwell, C. H., Chatters, L. M., Billingsley, A., \& Taylor, R. J. (1995). Church-based support programs for elderly Black adults: Congregational and clergy characteristics. In M. A. Kimble, S. H. McFadden, J. W. Ellor, \& J. J. Seeber (Eds.), Handbook on religion, spirituality, and aging. Minneapolis, MN: Augsburg Fortress Publishers.

Cassel, J. (1976). The contribution of the social environment to host resistance. American Journal of Epidemiology, 104, 107-123.

Chatters, L. M. (2000). Religion and health: Public health research and practice. Annual Review of Public Health, 21, 335-367.

Chatters, L. M., Mattis, J., Woodward, A. T., Taylor, R. J., Neighbors, H. W., \& Grayman, N. A. (2011). Use of ministers for a serious personal problem among African Americans: Findings from the National Survey of American Life. American Journal of Orthopsychiatry, 81, 118-127.

Chatters, L. M., Taylor, R. J., Bullard, K. M., \& Jackson, J. S. (2009). Race and ethnic differences in religious involvement: African Americans, Caribbean Blacks and Non-Hispanic Whites. Ethnic and Racial Studies, 32, 1143-1163.

Chatters, L. M., Taylor, R. J., Jackson, J. S., \& Lincoln, K. D. (2008). Religious coping among African Americans, Caribbean Blacks, and non-Hispanic Whites. Journal of Community Psychology, 36(3), 371-386.

Chatters, L. M., Taylor, R. J., Lincoln, K. D., \& Schroepfer, T. (2002). Patterns of informal support from family and church members among African Americans. Journal of Black Studies, 33, 66-85.

Compton, M. T., Thompson, N. J., \& Kaslow, N. J. (2005). Social environment factors associated with suicide attempt among low-income African Americans: The protective role of family relationships and social support. Social Psychiatry and Psychiatric Epidemiology, 40, 175-185.

Early, K. E. (1992). Religion and suicide in the African-American community. Westport, CT: Greenwood.

Ellison, C. E., \& Levin, J. S. (1998). The religion-health connection. Health Education \& Behavior, 25, 700-720.
Heeringa, S. G., Wagner, J., Torres, M., Duan, N., Adams, T., \& Berglund, P. (2004). Sample designs and sampling methods for the Collaborative Psychiatric Epidemiology Studies (CPES). International Journal of Methods in Psychiatric Research, 13, 221-240.

House, J. S., Landis, K. R., \& Umberson, D. (1988). Social relationships and health. Science, 241, 540-545.

Jackson, J. S., Torres, M., Caldwell, C. H., Neighbors, H. W., Nesse, R. M., Taylor, R. J., . . Williams, D. R. (2004). The National Survey of American Life: A study of racial, ethnic, and cultural influences on mental disorders and mental health. International Journal of Methods in Psychiatric Research, 13, 196-207.

Joe, S., Baser, R. E., Breeden, G., Neighbors, H. W., \& Jackson, J. S. (2006). Prevalence of and risk factors for lifetime suicide attempts among Blacks in the United States. Journal of the American Medical Association, 296(17), 2112-2123.

Kaslow, N. J., Price, A. W., Wyckoff, S., Grall, M. B., Sherry, A., \& Young, S. (2004). Person factors associated with suicidal behavior among African American women and men. Cultural Diversity and Ethnic Minority Psychology, 10(1), 5-22.

Kaslow, N. J., Thompson, M. P., Okun, A., Price, A., Young, S., Bender, M., ... Goldin, J. (2002). Risk and protective factors for suicidal behavior in abused African American women. Journal of Consulting and Clinical Psychology, 70(2), 311-319.

Kessler, R. C., Andrews, G., Mroczek, D., Ustun, B., \& Wittchen, H. (1998). The World Health Organization Composite International Diagnostic Interview short-form (CIDI-SF). International Journal of Methods in Psychiatric Research, 7(4), 171-185.

Kessler, R. C., Berglund, P., Borges, G., Nock, M., \& Wang, P. S. (2005). Trends in suicide ideation, plans, gestures, and attempts in the United States, 1990-1992 to 2001-2003. Journal of the American Medical Association, 293(20), 2487-2495.

Kessler, R. C., \& Ustun, T. B. (2004). The World Mental Health (WMH) survey initiative version of the World Health Organization (World Health Organization) Composite International Diagnostic Interview (CIDI). International Journal of Methods in Psychiatric Research, 13, 93-121.

Koenig, H. G., McCullough, M. E., \& Larson, D. B. (2001). Handbook of religion and health. New York, NY: Oxford University Press.

Krause, N. (2002a). Church-based social support and health in old age: Exploring variations by race. Journals of Gerontology: Social Sciences, 57B, S332-S347. 


\section{Church Support and Suicidal Risk}

Krause, N. (2002b). Exploring race differences in a comprehensive battery of church-based social support measures. Review of Religions Research, 44, 126-149.

Krause, N. (2004). Common facets of religion, unique facets of religion, and life satisfaction among older African Americans. Journal of Gerontology: Social Sciences, 59B(2), S109-S117.

Krause, N. (2006a). Church-based social support and change in health over time. Review of Religious Research, 48(2), 125-140.

Krause, N. (2006b). Church-based social support and mortality. Journal of Gerontology: Social Science, 61B(3), S140-S146.

Krause, N. (2008). Aging in the church: How social relationships affect health. West Conshohocken, PA: Templeton Foundation Press.

Krause, N. (2010). Close companions at church, health, and health care use in late life. Journal of Aging Health, 22(4), 434-453.

Krause, N., Chatters, L. M., Meltzer, T., \& Morgan, D. L. (2000). Negative interaction in the church: Insight from focus groups with older adults. Review of Religious Research, 41, 510-533.

Krause, N., Ellison, C. G., \& Wulff, K. M. (1998). Church-based social support, negative interaction, and psychological well-being: Findings from a national sample of Presbyterians. Journal for the Scientific Study of Religion, 37, 725-741.

Krause, N., \& Wulff, K. M. (2005). Church-based social ties, a sense of belonging in a congregation and physical health status. International Journal for the Psychology of Religion, 15, 73-93.

Landecker, W. S. (1951). Types of integration and their measurement. American Journal of Sociology, 56, 332-340.

Levin, J. S., \& Chatters, L. M. (2008). Religion, aging, and health: Historical perspectives, current trends, and future directions. Journal of Religion, Spirituality \& Aging, 20(1-2), 153-172.

Lincoln, K. D. (2000). Social support, negative social interactions, and psychological well-being. Social Service Review, 74, 231-252.

Lincoln, C. E., \& Mamiya, L. H. (1990). The Black Church in the African American experience. Durham, NC: Duke University Press.

Lincoln, K. D., Chatters, L. M., \& Taylor, R. J. (2003). Psychological distress among Black and White Americans: Differential effects of social support, negative interaction and personal control. Journal of Health and Social Behavior, 44(3), 390-407.
Lincoln, K. D., Taylor, R. J., \& Chatters, L. M. (2003). Correlates of emotional support and negative interaction among Black Americans. Journals of Gerontology: Social Sciences, 53B, S225-S233.

Maynard-Reid, P. U. (2000). Diverse worship: African-American, Caribbean and Hispanic perspectives. Downers Grove, IL: InterVarsity Press.

McAlister, E. (1998). The Madonna of 115th Street revisited: Vodou and Haitian Catholicism in the age of transnationalism. In R.S. Warner \& J.G. Wittner (Eds.) Gatherings in diaspora: Religious communities and the new immigration (pp. 123-160). Philadelphia, PA: Temple University Press.

Neeleman, J., Wessley, S., \& Lewis, G. (1998). Suicide acceptability in African and White Americans: The role of religion. Journal of Nervous and Mental Disease, 186, 12-16.

Nye, F., \& Rushing, W. (1969). Toward family measurement research. In J. Hadden \& E. Borgatta (Eds.), Marriage and family (pp. 133-140). Itasca, IL: F.E. Peacock.

Rook, K. S. (1984). The negative side of social interaction: Impact on psychological well-being. Journal of Personality and Social Psychology, 46, 1097-1108.

Sackett, P. R., \& Larson, J. R. (1990). Research strategies and tactics in industrial and organizational psychology. In M. D. Dunnette \& L. M. Hough (Eds.), Handbook of industrial and organizational psychology (pp. 419-428). Palo Alto, CA: Consulting Psychologists Press.

Taylor, R. J. \& Chatters, L. M. (1986a). Church-based informal support networks among elderly blacks. The Gerontologist, 26, 637-642.

Taylor, R. J. \& Chatters, L. M. (1986b). Patterns of informal support to elderly black adults: The role of family, friends, and church members. Social Work, 31, 432-438.

Taylor, R. J., \& Chatters, L. M. (1988). Church members as a source of informal social support. Review of Religious Research, 30, 193-203.

Taylor, R. J., Chatters, L. M., \& Jackson, J. S. (2007). Religious and spiritual involvement among older African Americans, Caribbean Blacks and Whites: Findings from the National Survey of American Life. The Journals of Gerontology: Social Sciences, 62, S238-S250.

Taylor, R. J., Chatters, L. M., \& Levin, J. (2004). Religion in the lives of African Americans: Social, psychological and health perspectives. Thousand Oaks, CA: Sage.

Taylor, R. J., Lincoln, K. D., \& Chatters, L. M. (2005). Supportive relationships with church 
members among African Americans. Family Relations, 54(4), 501-511.

Waters, M. C. (1999). Black identities: West Indian immigrant dreams and American realities. New York, NY: Russell Sage Foundation.
World Health Organization. (2004). The prevalence, severity, and unmet need for treatment of mental disorders in the World Health Organization World Mental Health Surveys. Journal of the American Medical Association, 291, 2581-2590. 